KONSTAN
JURNAL FISIKA DAN PENDIDIKAN FISIKA
Volume 5, Nomor 1, Juni 2020
$\begin{gathered}\text { E-ISSN : 2460-9129 dan P-ISSN : 2460-9110 } \\ \text { http://jurnalkonstan.ac.id/index.php/jurnal }\end{gathered}$

\title{
UPAYA MENINGKATKAN DISIPLIN GURU DALAM KEHADIRAN MENGAJAR DI KELAS MELALUI PENERAPAN REWARD AND PUNISHMENT SMA NEGERI 1 TUAL
}

\author{
Fata Tukloy ${ }^{1 *}$, Bahtiar $^{2)}$ \\ 1)* Sekolah Menengah Atas Negeri 1 Tual, Jln. Karel Sadsuittubun, Kota Tual, Maluku \\ 2) Program Studi Tadris Fisika, Fakultas Tarbiyah dan Keguruan, Universitas Islam Negeri \\ Mataram, Indonesia
}

\begin{tabular}{l}
\hline Info Artikel \\
\hline Sejarah Artikel: \\
Diterima \\
Disetujui \\
Dipublikasikan
\end{tabular}

Kata Kunci:

Penerapan Reward And

Punishment, Disiplin Guru,

Penelitian Tindakan Sekolah

(PTS)

\begin{abstract}
Abstrak
Penelitian ini bertujuan untuk mencari alternatif pemecahan masalah sebagai upaya meningkatkan disiplin guru dalam kehadiran mengajar di kelas melalui penerapan Reward and Punishment di SMA negeri 1 Tual. Subjek penelitian ini adalah semua guru mata pelajaran di SMA N 1 Tual yang berjumlah 78 orang. Penelitian ini merupakan penelitian kualitatif dengan menggunakan metode penelitian tindakan sekolah (PTS) yang mengacu pada model Kemmis dan Mc Taggart yang dilakukan sebanyak dua siklus. Setiap siklus terdiri dari empat tahapan, yaitu: 1) Perencanaan Tindakan, 2) Pelaksanaan Tindakan, 3) Observasi Tindakan, dan 4) Refleksi. Hasil penelitian ini menunjukkan bahwa Melalui Penerapan Reward and Punishment Pada SMA Negeri 1 Tual dapat meningkatkan disiplin guru dalam kehadiran mengajar di kelas." Rerata hasil capaian pada siklus I adalah 8,20\% dan rata-rata capaian pada siklus II 89,48 \% Jumlah guru yang masuk mengajar tepat waktu atau terlambat kurang dari 10 menit melebihi target yang ditetapkan yakni $75 \%$. Hal ini jelas menunjukkan bahwa terjadi peningkatan signifikan dari disiplin guru pada siklus II. Selain itu model model peenerpan Reward and Punishment ternyata sangat efektif diterapkan pada SMA Negeri 1 Tual.
\end{abstract}

(C) 2020 Universitas Islam Negeri Mataram

\footnotetext{
* Corresponding Author: fatatukloy@gmail.com
}

Alamat korespodensi: Sekolah Menengah Atas Negeri 1 Tual, Jln. Karel Sadsuittubun, Kota Tual, Maluku

Email: info@smansatual.sch.id 


\section{PENDAHULUAN}

Usaha meningkatkan mutu pendidikan sesuai dengan cita-cita bangsa Indonesia, untuk mewujudkan kesejahteraan umum dan mencerdaskan kehidupan bangsa, di mana pendidikan mempunyai peranan penting dalam meningkatkan ketakwaan kepada Tuhan Yang Maha Esa, kecerdasan, dan ketrampilan. Untuk meningkatkan peranan guru dalam proses belajar mengajar dan hasil belajar siswa, maka guru diharapkan mampu menciptakan lingkungan belajar yang efektif dan akan mampu mengelola kelas. Keberhasilan proses pembelajaran sangat bergantung pada beberapa faktor diantaranya adalah faktor guru. Guru sangat memegang peranan penting dalam keberhasilan proses pembelajaran. Guru yang memiliki kompetensi yang baik tentunya akan sangat mendukung keberhasilan proses pembelajaran [1].

Peranan guru selain sebagai seorang pengajar, guru juga berperan sebagai seorang pendidik. Pendidik adalah setiap orang yang dengan sengaja mempengaruhi orang lain untuk mencapai tingkat kemanusiaan yang lebih tinggi [2]. Untuk melaksanakan tugas dalam meningkatkan mutu pendidikan maka diadakanlah proses belajar mengajar, guru merupakan figure sentral, ditangan gurulah terletak kemungkinan tercapai atau tidaknya tujuan belajar mengajar di sekolah [3]. Sehinggga sebagai pendidik, guru harus memiliki kesadaran dan kewajiban untuk mendidik. Keteladanan guru dapat di lihat dari perilaku guru sehari-hari baik di dalam sekolah maupun di luar sekolah. Selain keteladanan guru, kedisiplinan guru juga menjadi salah satu hal penting yang harus dimiliki oleh guru sebagai pengajar dan pendidik. Temuan di lapangan sering kita jumpai guru kurang disiplin ketika masuk ke dalam kelas ketika pembelajaran dimulai [4].

Ketidak tepatan guru dalam masuk kelas juga akan menyebabkan siswa akan melakukan tindakan-tindakan yang dapat mengganggu ketenangan dan ketertiban kelas, sehingga dapat memberikan dampak yang tidak baik dalam manajemen sekolah. Penerapan disiplin perlu menjadi proritas kepala sekolah, salah satu bentuk pendisiplinan guru ini adalah dengan pemberian Reward and Punishment, yang mana mampu memberikan motivasi bagi seseorang untuk merubah kebiasaan yang kurang baik dan untuk meningkatkan prestasi seseorang. Berdasarkan uraian diatas, maka perlu dilakukan penelitian yang melihat penerapan Reward and Punishment mampu meningkatkan kedisiplinan guru dalam proses belajar mengajar di kelas.

\section{METODE PENELITIAN}

Penelitian tindakan sekolah dilakukan di SMA Negeri 1 Tual, pada semester genap tahun ajaran 2018/2019. Adapun yang menjadi subjek penelitian tindakan sekolah ini adalah guru-guru yang mengajar di SMA Negeri 1 Tual. Metode yang digunakan dalam penelitian ini adalah metode Penelitian Tindakan Sekolah (PTS) [5]. Kegiatan penelitian tindakan sekolah ini, terdiri atas beberapa tahap, yaitu : (1) Perencanaan; (2) Pelaksanaan; (3) Pengamatan; (4) Refleksi [6]. Permasalahan dalam penelitin ini ditindaklanjuti dengan cara menerapkan sebuah model pembinaan kepada guru berupa penerapan Reward dan Punishment yang dilakukan oleh kepala sekolah, kegiatan tersebut diamati, dianalisis dan direfleksikan. Hasil refleksi kemudian diterapkan kembali pada siklus-siklus berikutnya. 
Langkah-langkah penelitian tindakan sekolah dapat digambarkan seperti gambar dibawah ini [7].

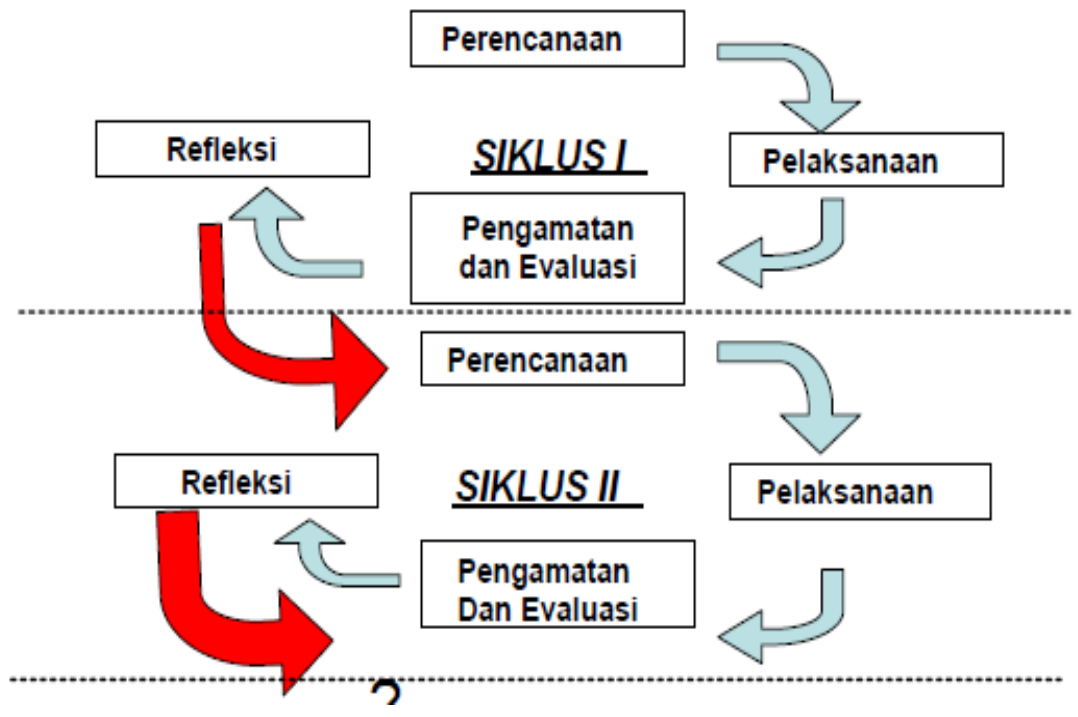

Gambar 1. Model Penelitian Tindakan Sekolah

Teknik pengumpulan data dari penelitian tindakan sekolah ini adalah melalui data kualitatif yang diperoleh dari observasi, pengamatan, maupun wawancara. Instrumen penelitian yang digunakan dalam penelitian tindakan sekolah ini antara lain adalah : Skala Penilaian, Lembar Pengamatan dan Pedoman wawancara. Analisa data yang digunakan dalam penelitian ini adalah analisa data kualitatif yang bersumber dari data primer maupun empiris. Melalui analisa data ini, dapat diketahui ada tidaknya peningkatan kedisiplinan guru dalam kehadiran dikelas melalui pemberian reward dan punishment yang merupakan fokus dari penelitian tindakan sekolah ini [7].

\section{HASIL DAN PEMBAHASAN}

Peneliti melakukan penilaian dari hasil lembar observasi yang dibagikan kepada pengurus kelas untuk mengamati kehadiran guru dikelas. Dari hasil pengamatan serta rekap yang dilakukan pada siklus I dan II dari tingkat kehadiran guru dikelas pada proses belajar mengajar dapat dilihat pada tabel 1 dan tabel 2 .

Berdasarkan hasil tabel 1, data siklus pertama tingkat keterlambatan guru masuk ke kelas diatas 15 menit rata- rata 65,32 \% dan 26,38 \% sedangkan guru masuk di kelas kurang dari 10 menit dengan rata-rata 8,20\% dan keluar lebih awal dengan rata-rata $36,90 \%$. Berdasarkan indikator yang telah ditetapkan bahwa keberhasilan tindakan ini adalah $75 \%$, atau bila $75 \%$ guru tidak terlambat lebih dari 10 menit [8]. 
Pada siklus pertama ini guru yang terlambat kurang dari 10 menit mencapai $8,20 \%$, jadi peneliti berkesimpulan harus diadakan perlakuan atau tindakan pada siklus kedua. Dari hasil refleksi didapatkan kesimpulan bahwa tingkat kedisiplinan guru terhadap waktu tergolong rendah dan hal tersebut sangat berpengaruh pada siswa, hal tersebut dapat dilihat dari hasil wawancara terhadap siswa tentang kehadiran guru di kelas, berdampak negatif bagi siswa apabila guru tidak disiplin dalam hal waktu pada proses pembelajaran yang dilakukan, ketidak disiplinan guru terhadap waktu akan mempengaruhi ketertiban siswa di kelas.

Tabel 1. Rekapitulasi Tingkat Keterlambatan Guru Pada Siklus I

\begin{tabular}{|c|c|c|c|c|c|}
\hline No & Kelas & Jam masuk & $\begin{array}{c}\text { Presentase } \\
(\%)\end{array}$ & Jam Keluar & $\begin{array}{c}\text { Presentase } \\
(\%)\end{array}$ \\
\hline \multirow{3}{*}{1} & \multirow{3}{*}{ Sepuluh (X) } & $<10$ menit & 5.35 & $<10$ menit & 37.97 \\
\hline & & $10-15$ menit & 69.52 & $10-15$ menit & 62.03 \\
\hline & & $>15$ menit & 25.13 & $>15$ menit & 0.00 \\
\hline \multirow{3}{*}{2} & \multirow{3}{*}{ Sebelas (XI) } & $<10$ menit & 10.70 & $<10$ menit & 37.43 \\
\hline & & $10-15$ menit & 62.57 & $10-15$ menit & 62.57 \\
\hline & & $>15$ menit & 26.74 & $>15$ menit & 0.00 \\
\hline \multirow{3}{*}{3} & \multirow{3}{*}{ Duabelas (XII) } & $<10$ menit & 8.56 & $<10$ menit & 35.29 \\
\hline & & $10-15$ menit & 64.17 & $10-15$ menit & 64.71 \\
\hline & & $>15$ menit & 27.27 & $>15$ menit & 0.00 \\
\hline
\end{tabular}

Tabel 2. Rekapitulasi Tingkat Keterlambatan Guru Pada Siklus II

\begin{tabular}{|c|c|c|c|c|c|}
\hline No & Kelas & Jam masuk & $\begin{array}{c}\text { Presentase } \\
(\%)\end{array}$ & Jam Keluar & $\begin{array}{c}\text { Presentase } \\
(\%)\end{array}$ \\
\hline \multirow{3}{*}{1} & \multirow{3}{*}{ Sepuluh (X) } & $<10$ menit & 85.56 & $<10$ menit & 83.42 \\
\hline & & $10-15$ menit & 14.44 & $10-15$ menit & 16.58 \\
\hline & & $>15$ menit & 0.00 & $>15$ menit & 0.00 \\
\hline \multirow{3}{*}{2} & \multirow{3}{*}{ Sebelas (XI) } & $<10$ menit & 90.91 & $<10$ menit & 94.65 \\
\hline & & $10-15$ menit & 9.09 & $10-15$ menit & 5.35 \\
\hline & & $>15$ menit & 0.00 & $>15$ menit & 0.00 \\
\hline \multirow{3}{*}{3} & \multirow{3}{*}{ Duabelas (XII) } & $<10$ menit & 91.98 & $<10$ menit & 90.37 \\
\hline & & $10-15$ menit & 8.02 & $10-15$ menit & 9.63 \\
\hline & & $>15$ menit & 0.00 & $>15$ menit & 0.00 \\
\hline
\end{tabular}

Siswa cendrung memiliki keterbatasan dalam belajar mandiri ketika tidak ada guru, karena guru adalah kompas untuk proses pembelajaran di kelas. Ketika guru datang terlambat maka secara tidak langsung mempengaruhi psikologis belajar siswa, satu sisi ada siswa yang merasa senang karena bisa bermain dan bercerita dengan teman-temanya dan di sisi yang lainnya siswa tidak senang karena tidak bisa belajar tepat waktu, jelas hal tersebut berpengaruh negatif terhadap motivasi belajar siswa. 
Ketidak dispilinan guru berdampak buruk terhadap proses pembelajaran. Pertama, siswa menjadi kecewa, dan hal ini dapat menurunkan motivasi belajar mereka, siswa mendapat contoh yang buruk tentang kedisiplinan. Kedua, guru yang mengajar dengan sungguh-sungguh merasa usahanya menjadi sia-sia dan sekaligus kecewa. Apa yang mereka bangun dipatahkan oleh rekan seprofesinya. Belum lagi, apabila guru yang disiplin dalam mengajar, memperoleh pendapatan yang sama dengan guru yang jarang mengajar di kelas.

Dari tabel 2 data persentase keterlambatan guru pada siklus kedua saat masuk kelas kurang dari 10 menit mencapai rata-rata 89,48 meningkat lebih signifikan dari siklus pertama, dan guru yang terlambat antara 10 sampai 15 menit adalah 10,52\% sedangkan dengan keterlambatan lebih dari 15 menit pada proses kegiatan belajar mengajar menunjukkan 0\%. Pada siklus kedua ini guru yang tidak terlambat lebih dari 10 menit mencapai $89,48 \%$. Hal ini merefleksikan bahwa tindakan yang dilakukan pada siklus kedua telah melebihi capaian target indikator pencapaian yang ditetapkan yakni 75\% [8]. Penerapan Reward and Punishment dapat meningkatkan disiplin guru hadir di dalam kelas pada kegiatan belajar mengajar di SMA Negeri 1 Tual . Reward (hadiah) merupakan metode yang bisa menga-asosia-kan perbuatan dan kelakuan seorang (kepala sekolah) dengan perasaan bahagia, senang, dan biasanya akan membuat mereka (guru) melakukan sesuatu perbuatan yang baik secara berulang-ulang. Selain motivasi, reward mampu membuat seseorang menjadi lebih giat dalam berusaha memperbaiki kinerja dan meningkatkan prestasi yang telah dicapai. Sedangkan Punishment diartikan sebagai hukuman atau sanksi.

Disamping pemberian Reward and Punishment ini, kepala sekolah juga perlu mengoptimalkan peraturan tata tertib dalam pelaksanaan pembelajaran sehingga pelaksanaan kedisiplinan guru pada proses mengajar dikelas dapat berjalan dengan baik. Supervisi terhadap guru secara terjadwal juga menjadi point penting dalam meningkatkan kedisiplinan guru. Kepala sekolah memiliki peranan sangat penting dan vital, kepala sekolah harus mampu memotivasi, melakukan pembinaan dan mengoptimalkan peraturan-peraturan kedisiplinan dalam pelaksanaan pembelajaran.

Penerapan kedisiplinan guru pada kehadiran di kelas dalam kegiatan belajar mengajar, bisa ditempuh dengan beberapa upaya. Adapun upaya dalam meningkatkan disiplin guru adalah sebagai berikut: (a) sekolah memiliki sistem pengendalian ketertiban yang dikelola dengan baik, (b) adanya keteladanan disiplin dalam sikap dan prilaku dimulai dari pimpinan sekolah, (c) mewajibkan guru untuk mengisi agenda kelas dan mengisi buku absen yang diedarkan oleh petugas piket, (d) pada awal masuk sekolah kepala sekolah bersama guru membuat kesepakatan tentang aturan kedisiplinan, (e) memperkecil kesempatan guru untuk ijin meninggalkan kelas, dan (f) setiap rapat pembinaan diumumkan frekuensi pelanggaran terendah. Dengan strategi tersebut diatas kultur disiplin guru dalam kegiatan pembelajaran bisa terpelihara dengan baik, suasana lingkungan belajar aman dan terkendali sehingga siswa bisa mencapai prestasi belajar yang optimal [9].

\section{SIMPULAN DAN SARAN}

Berdasarkan analisis data, dari penelitian ini dapat ditarik kesimpulan: Pertama, Data yang diperoleh menunjukan bahwa setelah diadakan penerapan tindakan Reward dan Punishment, guru masuk kelas kurang dari 10 menit mencapai rata-rata $89,48 \%$ meningkat lebih signifikan dari siklus pertama, dan guru yang terlambat antara 10 sampai 15 menit adalah $10,52 \%$, sedangkan keterlambatan 
lebih dari 15 menit pada proses kegiatan belajar mengajar menunjukkan 0\%. Hal ini merefleksikan bahwa tindakan yang dilakukan pada siklus kedua telah melebihi dari target indicator pencapaian yang ditetapkan yakni $75 \%$. Kedua, Pemberian rewards and punishments sangat berkaitan dengan terlaksananya kedisiplinan guru dalam kegiatan belajar mengajar dikelas. Kepala sekolah selaku pemimpin pada lembaga pendidikan memiliki peran yang sangat strategis dalam pencapaian tujuan sekolah dalam meningkatkan mutu. Ketiga, Penerapan Reward dan Punishment dapat meningkatkan disiplin guru hadir di dalam kelas pada kegiatan belajar mengajar di SMA Negeri 1 Tual.

Melihat dari hasil penelitian yang memberikan pengaruh positif pada penerapan Reward dan Punishment terhadap disiplin guru pada saat kehadiran tepat waktu di dalam kelas, saran-saran yang dapat diberikan sebagai berikut: Pertama, kepada semua kepala sekolah disarankan menerapkan Reward dan Punishment untuk meningkatkan kedisplinan guru ketika masuk ke kelas tepat waktu. Kedua, sebagai bentuk pelayanan pada peserta didik.

\section{DAFTAR PUSTAKA}

[1] Mulyasa, E. 2015. Standar Kompetensi Guru dan Sertifikasi Guru. Bandung: Remaja Rosdakarya

[2] Supriyo. 2018. Upaya Meningkatkan Displin Guru Dalam kehadiran Mengajar di Kelas melalui Penerapan Reward and Punishment di SMA Islam Darul Huda Lirik Kabupaten Indragiri Hulu. Jurnal Pendidikan Tambusai. Vol 2, Nomor 6.

[3] Zaenuddin. 2018. Upaya Meningkatkan Displin Guru Dalam kehadiran Mengajar di Kelas melalui Penerapan Reward and Punishment di SMP Negeri 5 Batukliang Kabupaten Lombok Tengah. Jurnal Pendidikan Berkarakter. Vol 1, Nomor 1

[4] Purwanto, J. 2017. Upaya Meningkatkan Disiplin Guru dalam Kehadiran Mengajar di Kelas Melalui Reward and Punishment di SDN Bandulan 1 Kecamatan Sukun Malang. Jurnal Pendidikan Dasar (JBPD). Vol 1, Nomor 2

[5] Supriyo. 2018. Upaya Meningkatkan Displin Guru Dalam kehadiran Mengajar di Kelas melalui Penerapan Reward and Punishment di SMA Islam Darul Huda Lirik Kabupaten Indragiri Hulu. Jurnal Pendidikan Tambusai. Vol 2, Nomor 6.

[6] Zaenuddin. 2018. Upaya Meningkatkan Displin Guru Dalam kehadiran Mengajar di Kelas melalui Penerapan Reward and Punishment di SMP Negeri 5 Batukliang Kabupaten Lombok Tengah. Jurnal Pendidikan Berkarakter. Vol 1, Nomor 1

[7] Supriyo. 2018. Upaya Meningkatkan Displin Guru Dalam kehadiran Mengajar di Kelas melalui Penerapan Reward and Punishment di SMA Islam Darul Huda Lirik Kabupaten Indragiri Hulu. Jurnal Pendidikan Tambusai. Vol 2, Nomor 6.

[8] Zaenuddin. 2018. Upaya Meningkatkan Displin Guru Dalam kehadiran Mengajar di Kelas melalui Penerapan Reward and Punishment di SMP 
Fata Tukloy dkk/KONSTAN Volume 5, Nomor 1, Halaman 35-41

Negeri 5 Batukliang Kabupaten Lombok Tengah. Jurnal Pendidikan Berkarakter. Vol 1, Nomor 1

[9] Purwanto, J. 2017. Upaya Meningkatkan Disiplin Guru dalam Kehadiran Mengajar di Kelas Melalui Reward and Punishment di SDN Bandulan 1 Kecamatan Sukun Malang. Jurnal Pendidikan Dasar (JBPD). Vol 1, Nomor 2 